J. Clin. Chem. Clin. Biochem.

Vol. 17,1979 , pp. $325-329$

\title{
Glucose-6-phosphate Dehydrogenase Deficiency: Biochemical and Histochemical Studies on Hair Roots for Carrier Detection
}

\author{
By A.J.M. Vermorken \\ Department of Pharmacology, Human Genetics and Biochemistry, \\ P. Wirtz
}

Department of Cytology and Histology,

G. Th. Spierenburg, C. A. van Bennekom, C. H. M. M. de Bruyn and T. L. Oei,

Department of Human Genetics,

University of Nijmegen, Nijmegen, The Netherlands

(Received August 7/December 11, 1978)

Summary: Kinetic properties of human hair root glucose-6-phosphate dehydrogenase and 6-phosphogluconate dehydrogenase were studied in order to optimize the assay of these enzymes in lysates from single hair roots. In contrast to previously reported methods, an excess of purified 6-phosphogluconate dehydrogenase was added to the glucose-6-phosphate dehydrogenase reaction mixtures, thus allowing a more exact quantification of glucose-6-phosphate dehydrogenase activity. Although enzyme histochemical techniques suggest a similar distribution of hair root glucose-6-phosphate dehydrogenase and 6-phosphogluconate dehydrogenase, enzyme assays on hair root segments after microdissection nevertheless indicate differences in the distribution of these enzymes. Upon storage a gradual drop in the activity of both hair root enzymes was found, but the rate of decrease in enzyme activity was about equal: the enzyme activity ratio was, therefore, not affected. This opens interesting possibilities for mailing hair roots for screening purposes without any special precautions.

\section{Glucose-6-phosphatdehydrogenase-Mangel: Biochemische und histologische Untersuchungen an Haarwurzeln zum Überträger-Nachweis}

Zusammenfassung: Die kinetischen Eigenschaften von Glucose-6-phosphat- und 6-Phosphogluconatdehydrogenase in Haarwurzeln des Menschen wurden untersucht, um die Bestimmung dieser Enzyme in Lysaten einzelner Haarwurzeln zu optimieren. Im Gegensatż zu früher veröffentlichten Methoden wurde den Bestimmungsansätzen für Glucose-6-phosphatdehydrogenase ein Úberschuß an 6-Phosphogluconatdehydrogenase zugefügt, was eine genauere Quantifizierung der Glucose-6-phosphatdehydrogenase erlaubt. Obwohl enzymhistochemische Untersuchungen eine gleichmäßige Verteilung von Glucose-6-phosphatdehydrogenase und 6-Phosphogluconatdehydrogenase annehmen lassen, zeigen Enżymbestimmungen an Haarwurzelsegmenten nach Mikrodissektion Unterschiede in der Verteilung dieser Enzyme. Nach Lagerung wịd ein allmählicher Abfall der Aktivität beider Haarwurzel-Enzyme gefunden; der Grad der Verminderung der Enzymaktivität war etwa gleich: das Verhältnis beider Enzymaktivitäten war deshalb nicht betröffen. Dies eröffnet interessante Möglichkeiten für den Vèrsand von Haarwurzeln für Screening-Untersuchungen ohne jede besondere Vorsichtsmaßnahmen.

\section{Introduction}

Glucose-6-phosphate dehydrogenase (EC 1.1.1.49) deficiency is an X-linked inherited enżyme defect, associated with haemólytic anaemia, upon ingestion of certain drugs or foods $(1-3)$. Glucose-6-phosphate dehydrogenase deficiency has also been implicated in the aetiology of severe neonatal jaundice leading to kernicterus (4-8). Heterozygous female carriers of the 
deficiency may be recognized by the fact that their erythrocyte activities of the enzyme fall in an intermediate range between normal and deficient values. However, certain female carriers may escape detection by the enzyme assay on red blood cells, because of an overlap of the glucose-6-phosphate dehydrogenase activities in normal homozygous, heterozygous and hemizygous individuals, respectively. Mosaicism based on X-chromosomal inactivation has been demonstrated in skin-derived fibroblasts from heterozygous female carriers, by means of cell cloning techniques (9), but this procedure is too complicated and time consuming to be used for screening purposes. Much more promising is the hair root analysis introduced by Gartler et al. (10), who showed that females heterozygous for the X-linked inherited hypoxanthine-guanine phosphoribosyl transferase (EC 2.4.2.8) deficiency can be rapidly detected by enzyme assays on individual hair roots. Evidence was presented that each hair root originates from a small number of cells $(10,11,12)$. The usefulness of hair root analysis in the detection of females heterozygous for hypoxanthine-guanine phosphoribosyl transferase deficiency was in general confirmed by several investigators $(13,14,15)$. Similar studies on female carriers of glucose-6-phosphate dehydrogenase deficiency were reported by Romeo et al. (16).

Glucose-6-phosphate dehydrogenase catalyzes the oxidation of glucose-6-phosphate to 6-phosphoglucono: lactone (reaction 1 in the reaction sequence), which is rapidly and spontaneously hydrolysed to 6-phosphogluconate. 6-Phosphogluconate dehydrogenase (EC 1.1.1.44) catalyzes the oxidation of 6-phosphogluconate to ribulose-5-phosphate and $\mathrm{CO}_{2}$ (reaction 3 in the reaction sequence):

(1) glucose-6-phosphate + NADP ${ }^{+} \rightarrow$ 6-phosphogluconolactone + $\mathrm{NADPH}+\mathrm{H}^{+}$

(2) 6-phosphogluconolactone $+\mathrm{H}_{2} \mathrm{O} \rightarrow$ 6-phosphogluconate

(3) 6-phosphogluconate $+\mathrm{NADP}^{+} \rightarrow$ ribulose-5-phosphate $+\mathrm{CO}_{2}+\mathrm{NADPH}+\mathrm{H}^{+}$.

Obviously, in the assay of glucose-6-phosphate dehydrogenase, based on the measurement of NADPH formation, 6-phosphogluconate dehydrogenase activity has to be taken into account. Depending on the relative activities of both enzymes in the individual hair root, between 1 and 2 moles of NADPH are formed per mole glucose-6phosphate oxidized. It is evident that the relative activities of the two enzymes in hair roots from normal controls differ from those in hair roots obtained from hemizygous glucose-6-phosphate dehydrogenase deficient individuals, while in heterozygous female carriers considerable variation is to be expected in the relative activities of glucose-6-phosphate dehydrogenase and 6-phosphogluconate dehydrogenase from hair root to hair root.

In this paper an accurate method is reported for the assay of glucose-6-phosphate dehydrogenase in indi- vidual hair roots, by adding an excess of commercially available 6-phosphogluconate dehydrogenase to the reaction mixture. In order to test the suitability of 6phosphogluconate dehydrogenase as a reference enzyme for glucose-6-phosphate dehydrogenase in hair root analysis, the distribution of both enzymes over the hair root was studied

(a) using enzyme histochemical techniques and

(b) measuring the enzyme activities in different portions of the hair root after microdissection.

Additionally, for the first time 6-phosphogluconate dehydrogenase in human hair roots was characterized kinetically.

\section{Materials and Methods}

\section{Chemicals}

Glucose-6-phosphate, 6-phosphogluconate, nicotinamide-adenine dinucleotide phosphate, oxidized form $\left(\mathrm{NADP}^{+}\right.$), and 6-phosphogluconate dehydrogenase were purchased from Boehringer, (Mannheim), 2-amino-2-methyl-1,3-propanediol, Tris (hydroxymethyl)-aminomethane, $\mathrm{MgCl}_{2} \cdot 6 \mathrm{H}_{2} \mathrm{O}$ and ethylenediamine tetraacetic acid, disodium salt (EDTA) from Merck, Darmstadt, and bovine serum albumin (fraction V) from Sigma, St. Louis.

\section{Enzyme assays on individual hair root lysates}

Human hair roots were plucked from several areas of the scalp and those with visible bulb and sheath (anagen phase) were cut off above the sheath and each one was put into $70 \mu \mathrm{l} 0.01 \mathrm{~mol} / \mathrm{l}$ Tris-HCl buffer, $\mathrm{pH} 7.4$, containing $1 \mathrm{~g} / 1$ bovine serum albumin. After 5 cycles of freezing $\left(-20^{\circ} \mathrm{C}\right)$ and thawing, $20 \mu$ laliquots of the root lysate were taken for the glucose-6-phosphate dehydrogenase assay and for the 6-phosphogluconate dehydrogenase assay.

For the glucose-6-phosphate dehydrogenase assay, the reaction was started by the addition of $20 \mu \mathrm{l}$ hair root lysate to $125 \mu \mathrm{l}$ of a mixture containing $20 \mathrm{mmol} / 1$ glucose-6-phosphate, $10 \mathrm{mmol} / 1 \mathrm{NADP}^{+}, 2.5 \mathrm{mmol} / 1 \mathrm{MgCl}_{2}, 0.5 \mathrm{mmol} / 1 \mathrm{EDTA}$, $0.5 \mathrm{~g} / 1$ bovine serum albumin and $0.1 \mathrm{~mol} / 1$ 2-amino-2-methyl1,3 propanediol buffer (pH 8.6) and $300 \mathrm{mU}$ 6-phosphogluconate dehydrogenase, unless otherwise indicated.

For the 6-phosphogluconate dehydrogenase assay, the reaction was started by the addition of $20 \mu \mathrm{l}$ of hair root lysate to $125 \mu \mathrm{l}$ of a mixture containing $10 \mathrm{mmol} / \mathrm{l} 6$-phosphogluconate, $5 \mathrm{mmol} / 1 \mathrm{NADP}^{+}, 2.5 \mathrm{mmol} / 1 \mathrm{MgCl}_{2}, 0.5 \mathrm{mmol} / 1 \mathrm{EDTA}$, $0.5 \mathrm{~g} / \mathrm{l}$ bovine serum albumin and $0.1 \mathrm{~mol} / 1$ 2-amino-2-methyl1,3 propanediol buffer $\mathrm{pH}$ 8.6.

After incubation for 3 hours at $37^{\circ} \mathrm{C}$ for the glucose-6-phosphate dehydrogenase assay and for 5 hours at $37^{\circ} \mathrm{C}$ for the 6=phosphogluconate dehydrogenase assay, the reactions were terminated by the addition of $1800 \mu 10.2 \mathrm{~mol} / 1 \mathrm{NaOH}$. Blanks were performed without hair root lysate. The NADPH formation was measured spectrophotometrically at $340 \mathrm{~nm}$.

\section{Enzyme assays on dissected hair roots}

Five hair roots were obtained from each of five different normal individuals. Hair roots were dissected by cutting them just above, through the middle and just below the sheath. The different parts are referred to as upper sheath, lower sheath and bulb, respectively. Each hair root fraction was pooled in $50 \mu \mathrm{l}$ buffer, homogenized by freezing and thawing, and assayed for glucose-6-phosphate dehydrogenase and 6-phosphogluconate dehydrogenase.

\section{Storage experiment}

Normal hair roots were kept at room temperature without any special precaution. At intervals glucose-6-phosphate dehydro- 
genase and 6-phosphogluconate dehydrogenase assays were performed during a period of 14 days.

\section{Enzyme histochemistry of the hair root}

Freshly obtained human hair roots were oriented for longitudinal sectioning in a saturated aqueous solution of methylcarboxycellulose, and chilled with $\mathrm{CO}_{2}$ gas. Sections of $10 \mu \mathrm{l}$ thickness were cut using a Walter Dittes Cryostat $\left(-25^{\circ} \mathrm{C}\right)$, taking care that the hair roots were sectioned longitudinally.

Activities of glucose-6-phosphate dehydrogenase and 6-phosphogluconate dehydrogenase were demonstrated histochemically according to the semi-permeable membrane method described by Meyer \& de Vries (17). The substrate end-concentration of glucose-6-phosphate and 6-phosphogluconate both is $0.12 \mathrm{~mol} / \mathrm{l}$ (after adjustment to $\mathrm{pH}$ 7.3). The sections were incubated for 45 minutes at $37^{\circ} \mathrm{C}$, fixed for 10 minutes in $40 \mathrm{~g} / \mathrm{l}$ formaldehyde macrodex and mounted in glycerol-gelatin.

\section{Results and Discussion}

Characteristics of human hair root glucose-6-phosphate dehydrogenase and 6-phosphogluconate dehydrogenase

The optimum $\mathrm{pH}$ for glucose-6-phosphate dehydrogenase and 6-phosphogluconate dehydrogenase was found to be 8.5 and 8.7 , respectively (fig. 1 a). For the measurement of both reactions under identical conditions a $\mathrm{pH}$ of 8.6 was chosen.

An apparent $K_{\mathrm{m}}$ of $3.1 \mathrm{mmol} / 1$ glucose-6-phosphate was calculated for glucose-6-phosphate dehydrogenase and $0.2 \mathrm{mmol} / 1$ 6-phosphogluconate for 6-phosphogluconate dehydrogenase (Lineweaver-Burk plots; fig. 1b).

An apparent $K_{\mathrm{m}}$ of 1.5 and $0.1 \mathrm{mmol} / 1 \mathrm{NADP}^{+}$was calculated for glucose-6-phosphate dehydrogenase and 6-phosphogluconate dehydrogenase, respectively (Lineweaver-Burk plots; fig. $1 \mathrm{c}$ ). These data were used to optimize the assay of both enzymes in human hair root lysates.

\section{Elimination of the effect of endogenous 6-phospho-} gluconate dehydrogenase activity on the glucose-6-phosphate dehydrogenase assay

Increasing amounts of purified 6-phosphogluconate dehydrogenase enhanced the rate of NADPH formation in the hair root glucose-6-phosphate dehydrogenase
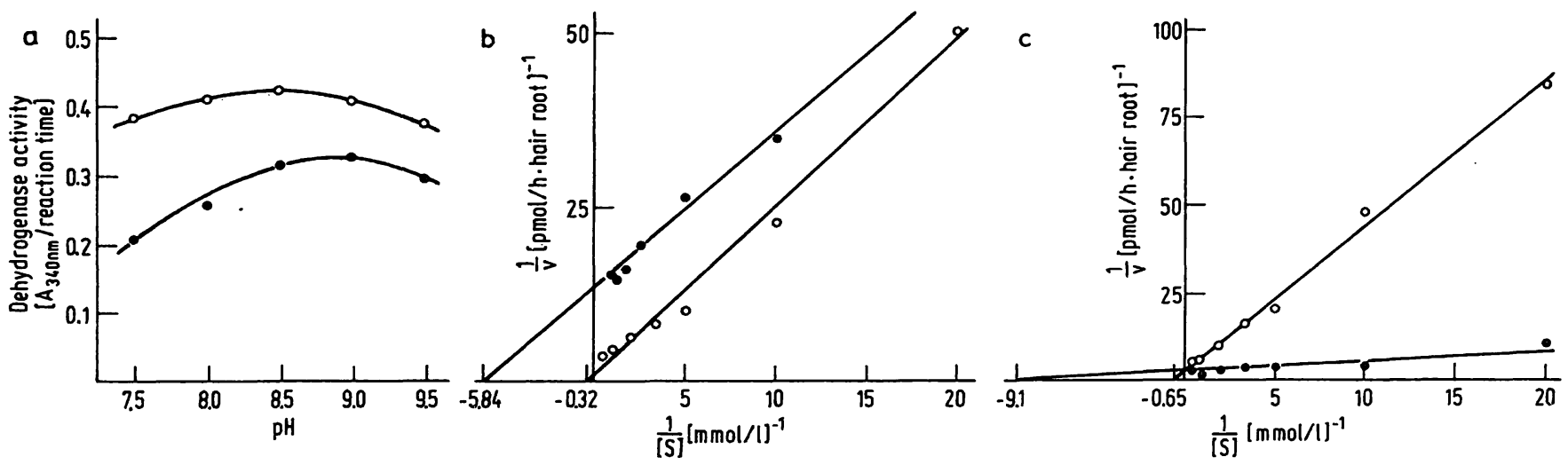

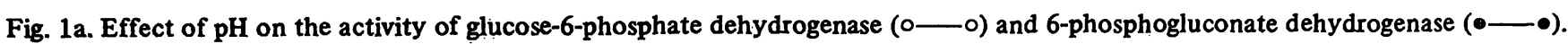

Fig. 1b. Lineweaver-Burk plots for the glucose-6-phosphate dehydrogenase reaction with glucose-6-phosphate (0-0) and for 6-phosphogluconate dehydrogenase with 6-phosphogluconate $(\bullet-\bullet)$ as substrate. $\frac{1}{v}$ is expressed as the reciprocal value of $\mathrm{pmol} / \mathrm{h} \cdot \mathrm{hair}$ root.

Fig. 1c. Lineweaver-Burk plots for the glucose-6-phosphate dehydrogenase reaction with NADP (0—- 0 ) and for 6-phosphogluconate

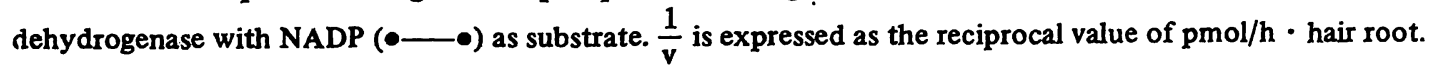

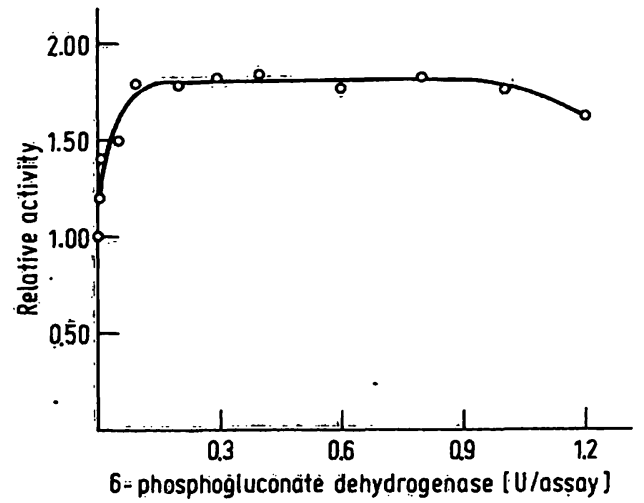

Fig. 2: Effect of varying amounts of purified 6-phosphogluconate dehydrogenase on the glucose-6-phosphate dehydrogenase activity. The amounts of 6-phosphogluconate dehydrogenase are indicated in $U$ per incubation mixture. assay. The maximal value was reached at about $200 \mathrm{mU}$ exogenous 6-phosphogluconate dehydrogenase, and then remained constant when purified enzyme was added (fig. 2). It was concluded that insufficient endogenous 6-phosphogluconate dehydrogenase activity was present in normal human hair roots to catalyze the immediate and complete conversion of 6-phosphogluconate to ribulose-5-phosphate and $\mathrm{CO}_{2}$; less than the maximum amount of 2 mol of NADPH is formed per mol glucose-6-phosphate converted in the assay system, resulting in an underestimation of glucose-6-phosphate dehydrogenase activity. The underestimation of glucose6-phosphate dehydrogenase activity should be less severe in the assay on glucose-6-phosphate dehydrogenase deficient hair roots because they contain a relative excess of endogenous 6-phosphogluconate 
dehydrogenase. Addition of $300 \mathrm{mU}$ purified 6-phosphogluconate dehydrogenase should improve the accuracy and discriminatory value of the quantitative measurement of hair root glucose-6-phosphate dehydrogenase activity.

In order to correct for different sizes of the individual hair roots endogenous 6-phosphogluconate dehydrogenase activities were assayed and used as a reference with respect to glucose-6-phosphate dehydrogenase activity measured in the same hair root, thus obviating protein estimations which are relatively inaccurate in such small samples. The glucose-6-phosphate dehydrogenase/6-phosphogluconate dehydrogenase activity ratio in 25 individual normal hair root lysates was 0.93 \pm 0.27 (mean \pm S.D.) in the absence of purified 6-phosphogluconate dehydrogenase in the glucose-6-phosphate dehydrogenase assay. In the same 25 hair root lyssates the ratio increased to $1.53 \pm 0.39$ (mean \pm S.D.) in the presence of purified 6-phosphogluconate dehydrogenase; this is to be expected, since glucose-6-phosphate dehydrogenase activity is underestimated without an excess of 6-phosphogluconate dehydrogenase activity. The range of enzyme activity ratios of normal hair root lysates is therefore shifted to higher values when extra 6-phosphogluconate dehydrogenase is included. For glucose-6-phosphate dehydrogenase deficient hair roots there will be hardly any difference: the enzyme activity ratios will stay very low. It follows that under these conditions in single hair roots from heterozygotes for glucose-6-phosphate dehydrogenase deficiency, a better separation can be obtained between deficient ratios (hair roots originated from only "mutant" cells), intermediate ratios (hair roots originated from both "normal" and "mutant" cells) and normal ratios (hair roots originated from "normal" cells). Therefore our method should permit a better separation between normal homozygotes and heterozygotes than methods reported previously (16).

\section{Enzyme histochemistry}

The major activity of glucose-6-phosphate dehydrogenase was located in the matrix and upper bulb. These parts showed intense staining (fig. 3a). Less intense staining was found in the outer root sheath, with somewhat more intensity of the staining in the inner part of the outer root sheath (fig. $3 \mathrm{~b}$ ). The same kind of distribution was found for 6-phosphogluconate dehydrogenase activity: figure 4 shows that the localisation of the latter enzyme more or less corresponds to that of glucose-6phosphate dehydrogenase.

\section{Microdissection studies}

In contrast to the histochemical studies, enżyme assays on different segments of the hair root revealed that the distribution of glucose-6-phosphate dehydrogenase and 6-phosphogluconate dehydrogenase are not completely identical.
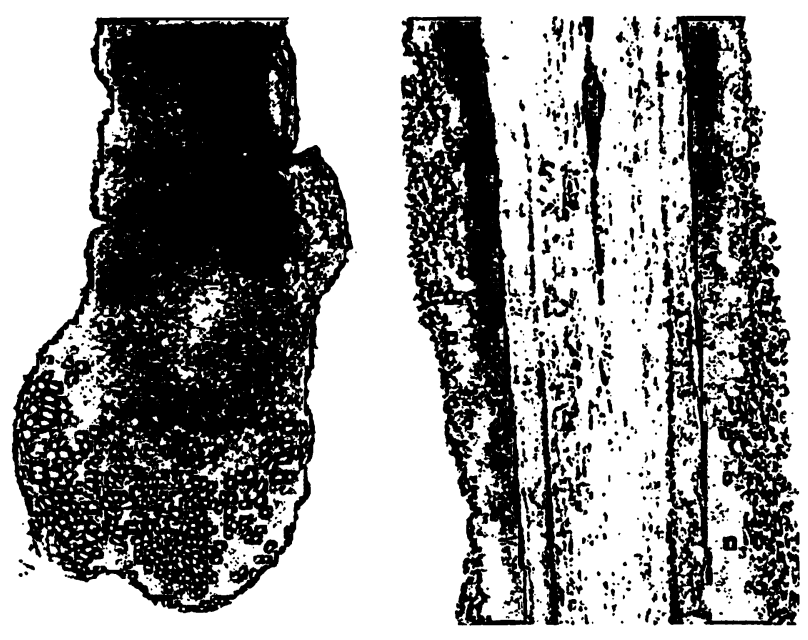

Fig. 3: Localisation of glucose-6-phosphate dehydrogenase activi-

ty.

a) The hair bulb; much activity is found in the matrix and upper bulb (magnification 875x).

b) Segment of the upper sheath. The inner part of the outer root sheath is the main site of enzyme activity (magnification 1400x).
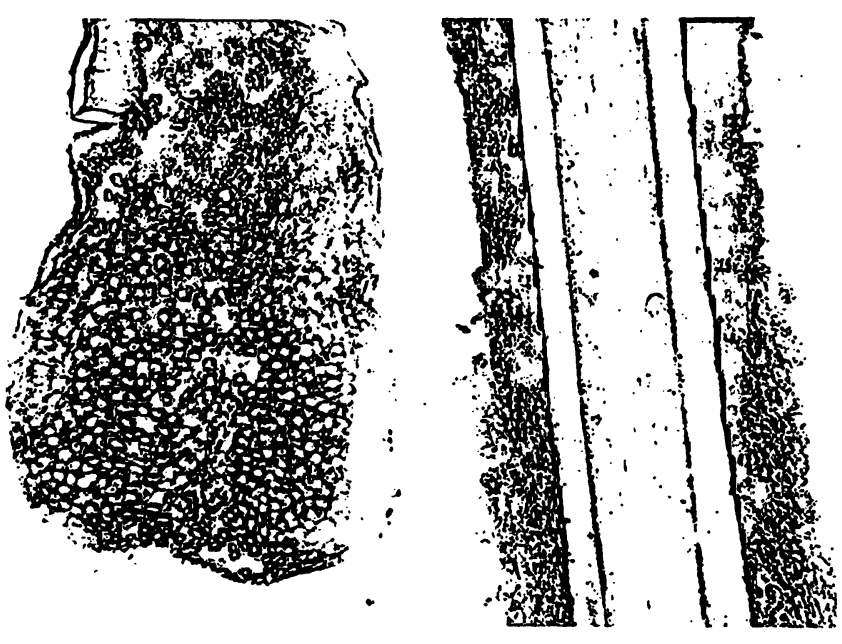

Fig. 4: Localisation of 6-phosphogluconate dehydrogenase activity.

a) The hair bulb; the localisation of the enzyme corresponds to that of glucose-6-phosphate dehydrogenase (magnification 1100x)

b) Segment of the upper sheath. Enzyme activity is mainly located in the outer root sheath; the inner part contains most of the activity (magnification 1400x).

Table 1 shows that most of the glucose-6-phosphate dehydrogenase activity was detected in the bulb, whereas most of the 6-phosphogluconate dehydrogenase activity was found in the upper sheath. The biochemically detected distribution of glucose-6-phosphate dehydrogenase is in agreement with the histochemical findings and confirms the report of Adachi \& Uno (18) who measured most of the activity in the lower portion of the human hair root.

The biochemical and histochemical methods of 6-phosphogluconate dehydrogenàse localisation yield different results. This may reflect differences in extractability of 
Tab. 1. Fraction of total activity in human hair root segments after microdissection.

\begin{tabular}{lll}
\hline & $\begin{array}{l}\text { Glucose-6-phosphate } \\
\text { dehydrogenase }\end{array}$ & $\begin{array}{l}\text { 6-phospho- } \\
\text { gluconate } \\
\text { dehydrogenase }\end{array}$ \\
\hline Upper sheath $(n=5)$ & $0.25 \pm 0.04$ & $0.42 \pm 0.03$ \\
Lower sheath $(n=5)$ & $0.33 \pm 0.03$ & $0.32 \pm 0.02$ \\
Bulb $(n=5)$ & $0.42 \pm 0.05$ & $0.26 \pm 0.02$ \\
\hline
\end{tabular}

the enzyme in the dissected parts of the hair root, or conversely it may indicate that the quantitative aspects of the histochemical method need to be studied in more detail.

The finding that the 6-phosphogluconate dehydrogenase distribution does not parallel the glucose-6-phosphate dehydrogenase distribution when studied by enzyme assay after microdissection of the hair root, suggests that 6-phosphogluconate dehydrogenase may not be the ultimate choice as a reference enzyme. However, since this enzyme is functionally closely related to glucose-6phosphate dehydrogenase it is conceivable that in hair root cells deficient for glucose-6-phosphate dehydrogenase activity there is a compensatory increase in 6phosphogluconate dehydrogenase activity, which results in an improvement of the discriminatory value of the glucose-6-phosphate/6-phosphogluconate dehydrogenase activity ratios. It seems, therefore, not justified to reject 6-phosphogluconate dehydrogenase as a reference enzyme completely, but it remains to be established which enzyme is best suited as a reference enzyme in hair root analysis for carrier detection of glucose-6-phosphate dehydrogenase deficiency.

\section{References}

1. Carson, P. E., Flanagan, C. L., Ickes, C. E. \& Alving, A. S. (1956), Science 124, 484-485.

2. Zinkham, W. H., Lenhard, R. E., Jr. \& Childs, E. (1958), Bull. Johns Hopkins Hosp. 102, 169-175.

3. Beutler, E. (1959), Blood 14, 103-139.

4. Smith, G. D. \& Vella, F. (1960), Lancet I, 1133-1134.

5. Weatherall, D. J. (1960), Lancet II, 835-837.

6. Panizon, F. (1960), Lancet II, 1093.

7. Doxiadis, S. A., Fessas, Ph. \& Valaes, T. (1961), Lancet I, 297-301.

8. Geerdink, R. A., Horst, R. \& Staal, G. E. J. (1973), Isr. J. Med. Sci. 9, 1040-1043.

9. Davidson, R. G., Nitowsky, H. M. \& Childs, B. (1963), Proc Natl. Acad. Sci. USA, 50, 481-485,

10. Gartler, S. M., Scott, R. C., Goldstein, J. L., Campbell, B. \& Sparks, R. (1971), Science 172, 527-574.

11. Gartler, S. M., Gandini, E., Angiono, G. \& Argiolas, N. (1969), Ann. Hum. Genet. 33, 171-176.

12. de Bruýn, C. H. M. M., Oei, T. L. \& ter Haar, B. G. A. (1974), Clin. Genet. 5, 449-456.

\section{Storage experiment}

Table 2 reveals that human hair roots can be stored for 3 days without any precaution with little loss of the activities of glucose-6-phosphate dehydrogenase and 6phosphogluconate dehydrogenase. Both enzymes then gradually decrease in activity at approximately the same rate. The enzyme activity ratio remains, therefore, unaffected even after 10 days. Because their enzymes (present study, 19, 20,21) are relatively stable, hair roots seem to be an attractive biopsy material for screening purposes: they might be collected in one place and without any precautions be mailed to laboratories where the enzyme assays can be carried out.

Tab. 2. Effect of storage on human hair root glucose-6-phosphate dehydrogenase and 6-phosphogluconate dehydrogenase.

Relative activity

\begin{tabular}{lll} 
Days & $\begin{array}{l}\text { Glucose-6-phos- } \\
\text { phate dehydro- } \\
\text { genase }\end{array}$ & $\begin{array}{l}\text { 6-phospho- } \\
\text { gluconate } \\
\text { dehydrogenase }\end{array}$ \\
\hline 0 & 1.00 & 1.00 \\
3 & 0.93 & 0.91 \\
7 & 0.77 & 0.78 \\
10 & 0.72 & 0.71 \\
14 & 0.51 & 0.60 \\
\hline
\end{tabular}

\section{Acknowledgements}

The authors wish to thank Prof. Dr. S. J. Geerts (head Dept. Human Genetics) and Dr. P. Mier (Dept. Dermatology) for stimulating discussions and critical reading of the manuscript. This study was supported by a grant from the Medical Prevention Fund, The Netherlands.
13. Silvers, D. N., Cox, R. P., Balis, E. \& Dancis, J. (1972), N. Engl. J. Med. 286, 390-393.

14. Francke, U., Bakay, B. \& Nyhan, W. L. (1973), J. Pediatr. $82,472-478$.

15. de Bruyn, C. H. M. M. (1976), Hum. Genet. 31, 127-150.

16. Romeo, G., Rinaldi, A., Urbano, F. \& Filippi, G. (1976), Am. J. Hum. Genet. 28, 506-513.

17. Meyer, A. E. F. H. \& de Vries, G. P. (1974), Histochem. 40, 349-359.

18. Adachi, K. \& Uno, H. (1968), Am. J. Physiol. 215, 12341239.

19. Vermorken, A. J. M., Weterings, P. J. J. M., Spierenburg, G. Th., van Bennekom, C. A., Wirtz, P., de Bruyn, C. H. M. M. \& Oei, T. L. (1978), Brit. J. Dermat. 98, 191-196.

20. Hösli, P., Schneck, L., Amsterdam, D., \& Volk, B. W. (1977), Lancet, $I, 285-287$.

21. Vermorken, A. J. M., van Bennekom, C. A., de Bruyn C. H. M. M., Oei, T. L. \& Fröhlich, J., submitted for publication.
Dr. A. J. M. Vermorken Department of Pharmacology, Human Genetics and Biochemistry, Faculty of Medicine, University of Nijmegen, Nijmegen, The Netherlands. 
